ISSN 1810-3030 (Print) 2408-8684 (Online)

\title{
Study of stingray harvesting, marketing and utilization in Cox's Bazar,
} Bangladesh

\author{
Md. Nagim Uddin ${ }^{1}$, Mahabubur Rahman ${ }^{2}$, Md. Jakir Hossain ${ }^{1}$, Israt Jahan Tumpa ${ }^{1}$ and \\ $\otimes$ Zakir Hossain ${ }^{1}$
}

${ }^{1}$ Department of Fisheries Biology and Genetics, Bangladesh Agricultural University, Mymensingh-2202, Bangladesh ${ }^{2}$ Department of Fisheries and Marine Science, Noakhali Science and Technology University, Noakhali-3804, Bangladesh

\begin{tabular}{|c|c|}
\hline ARTICLE INFO & Ab \\
\hline 2018 & \multirow{3}{*}{ 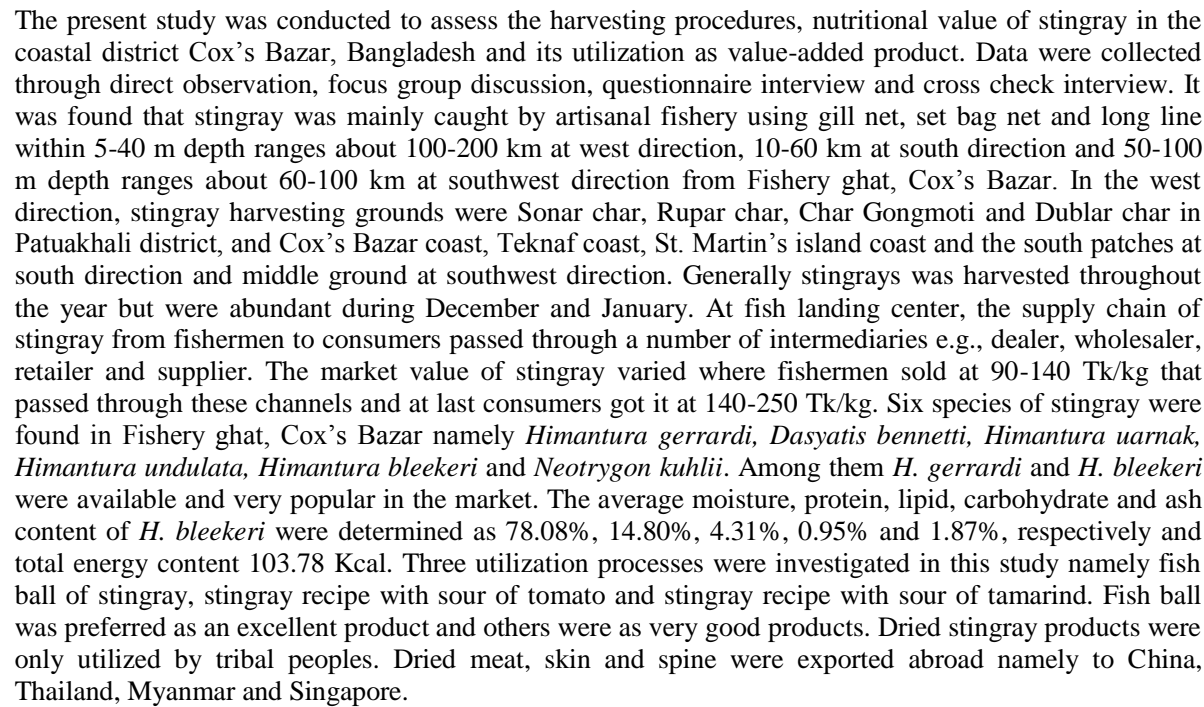 } \\
\hline Iacronutrients; Utilization & \\
\hline & \\
\hline
\end{tabular}

\section{Copyright:}

(c) (7)

(O2018 by authors and BAURES. This work is licensed under the Creative Commons Attribution International License (CC By 4.0).

\section{Introduction}

Fisheries sector plays an important role in the economy in terms of nutrition, food security, alleviating protein shortage, income, employment and socio-economic development and foreign exchange earnings of Bangladesh. Fisheries sector was contributed $2.01 \%$ of the total export earnings and 3.69\% to the GDP (DoF, 2015). The marine fisheries sector of Bangladesh is divided into coastal or artisanal fisheries and deep sea or industrial fisheries. The average of last ten years' production shows that the artisanal small scale fisheries were contributing $93.4 \%$ of the total marine landing (Hussain and Rahman, 2010). Total landing of sharks and rays was only $0.95 \%$ of the total marine fish production of Bangladesh (DoF, 2014). The multispecies coastal fisheries comprises of 11 species of sharks and 16 species of rays (Roy, 2011). Rays are usually captured for its high value fins but flesh has some demand in the tribal area of Bangladesh (Roy et al., 2014). The majority parts of flesh being dried and salted for export. Although, stingray have not been highly priced product in the local market of Bangladesh comparing with other marine commercial fishes. However, stingrays are a good source of protein and are low in fat content. Common stingrays contain $76.59 \pm 1.87 \%$ moisture, $2.96 \pm 0.02 \%$ ash, $19.35 \pm 0.56 \%$ protein and $0.75 \pm 0.00 \%$ lipid (Ünlüsayin et al., 2011). Stingray is one of the most acceptable and popular fish species to be smoked in Indonesia especially processed by traditional method (Swastawati et al., 2012). Fish flake is an intermediate moisture fish product which is made from stingray meal, Tapioca starch and curing ingredients (Mardiah et al., 2010). It is very popular in Malaysia and China. In South America, the product that is quite similar to fish flake is called jerky. Jerky has been a favorite snack food for many years (Carr et al., 1997). There is lack of information about nutritional composition and the utilization process of the meat of stingray in Bangladesh. So, the study was undertaken to give a clear information on marketing channel, nutritional composition and utilization processes of meat of stingray in Bangladesh. 


\section{Materials and Methods}

\section{Study area}

The study was conducted for a period of six months from July to December 2016. Information through questionnaire was collected from landing centers of Cox's Bazar because the major portions of rays were landed here and the wholesale and retail markets were also located in that place. The study was also taken place at Nazirtekh and Mukhshidapara of Cox's Bazar district where rays are processed as salted or dried form for utilization and from where rays skin are usually processed for export market and the meat part was sold for local consumption mostly to the tribal community. The study was also taken place at different local area of Cox's Bazar city mainly Mogpara and Barmiz market area where many people are utilize rays in many ways.

\section{Data collection}

For data collection, direct observation was taken in study area to get data. Six questionnaires were prepared based on these information in accordance with the objectives set for the study. The final questionnaires developed in logical and perfect sequence so that the interviewers could answer of these questions chronologically. For questionnaire interviews, simple random sampling method was followed for 50 fishermen, 20 retailers, 60 consumers, 20 dry processors. Focus Group Discussion (FGD) tool such as, Participatory Rural Appraisal (PRA) and Rapid Rural Appraisal (RRA) tools were conducted with dealer, wholesalers, members of fishermen association, members of trader association, members of market association and local consumers in local restaurants in Sadar, Cox's Bazar. Cross interviews were conducted with the person i.e. fish landing center survey officers. The species were identified locally through eye observation and detected the lowest probable taxonomic rank by the help of Quddus (1988) and Bonfil and Mohamed (2003). All the collected data were recorded carefully and summarized.

\section{Proximate composition analysis}

Proximate compositions were analyzed in the Fish Technology Laboratory of Bangladesh Council of Scientific and Industrial Research (BCSIR), Dhaka.

Moisture: Moisture content was determined in triplicate by placing an accurately weighed amount (about 7-8 g ground sample in a pre-weighed porcelain crucible in a hot air oven (Gallenkamp, HOTBOX, Model OVB-305) at $105{ }^{\circ} \mathrm{C}$ for $24 \mathrm{~h}$ until a constant weight was obtained. The loss of weight was calculated as percent moisture content using this formula:

Moisture $(\%)=$ $\frac{\text { Original sample weight }(\mathrm{g}) \text { - Dried sample weight }(\mathrm{g})}{\text { Original sample weight }(\mathrm{g})} \times 100$

Ash: Ash content of the sample was determined by igniting sample about 4-5 $\mathrm{g}$ in a Muffle Furnace (Philip Harris Ltd, England), for $6 \mathrm{~h}$ at a temperature of 550 $800^{\circ} \mathrm{C}$. After cooling, the crucible was weighed again. The ash content was calculated and expressed as percentage of the original sample using the following formula:

$$
\operatorname{Ash}(\%)=\frac{\text { Weight of ash }(\mathrm{g})}{\text { Weight of sample }(\mathrm{g})} \times 100
$$

Crude protein: Kjeldahl method was used to determine protein content of the fish samples. The data were taken by doing duplicate analyses for protein. The following formulas were used:

$\%$ Nitrogen $=$
$\frac{\text { Milliequivalent of nitrogen }(0.014) \times \text { Titrant value }(\mathrm{ml}) \times \text { Strength of } \mathrm{HCl}}{\text { Weight of sample }(\mathrm{g})} \times 100$

Crude Protein $(\%)=6.25 \%$ Nitrogen, for animal source Crude Protein $(\%)=5.87 \%$ Nitrogen, for plant source

Crude lipid: Lipid content was determined by soxhlet apparatus using acetone as solvent. Prepared feed sample was weighed (within approximately 3-5 g sample was taken) and then taken in a paper thimble and placed it inside the soxhlet apparatus. Sufficient amount (about $170 \mathrm{ml}$ ) of acetone was poured into the round joint flask of the apparatus and heated on water bath at $70^{\circ} \mathrm{C}$ for $1.5-2.0 \mathrm{~h}$. The solvent evaporates upon heating but allowed to drop slowly after condensing on the sample inside the thimble until the entire lipid in the sample was extracted. Finally the solvent containing lipid was transferred to a pre-weighed beaker. The residual lipid content was obtained after removal of solvent by evaporating on heating on water bath. The percentage of total lipid was calculated using the following formula:

Total lipid $(\%)=\frac{\text { Weight of lipid }(\mathrm{g})}{\text { Weight of sample }(\mathrm{g})} \times 100$

\section{Experiment on stingray products}

Experimental fish species: In the present study, among different species of stingray, Himantura gerrardi (Shada shapla patha) was selected. The species were selected considering the popularity, availability and taste.

Experimental design: For this experiment, it was categorized into 3 treatments. The first treatment composed of Potato, Onion, Garlic, Ginger, Pepper, Tomato, Sugar, Tasting salt, Salt, Turmeric's powder, Coriander's powder, Lemon, Egg, Biscuit's powder (without sugar), Soybean Oil, Soya sous, Coriander leaf and Tej pata. Another was Treatment 2 that contains oil, onion, garlic, ginger, salt, Turmeric's powder, Pepper's powder, Pepper, Tomato and Masala powder. The third treatment contained Oil, Garlic, Ginger, Onion, Pepper, Turmeric's powder, Pepper's powder, Salt, Sugar, Masala powder and Tamarind sour (Table 1). 
Collection of samples: The samples were bought from the fishery ghat, Cox's Bazar during the morning hours of the day (between 9.30 am to 10.00 am local time). The fish samples were collected in sterilized ice box with full of flake ice. Samples were later transported to the laboratory, using icebox within 10 hours. For each treatment, $250 \mathrm{~g}$ muscle of stingray was collected.

Table 1. Name of ingredients and amounts used in treatment 1,2 and 3

\begin{tabular}{lccc}
\hline \multicolumn{1}{c}{ Namgredients } & Treatment 1 & Treatment 2 & Treatment 3 \\
\cline { 2 - 4 } & Amounts & Amounts & Amounts \\
\hline Sting ray & $250 \mathrm{~g}$ & $250 \mathrm{~g}$ & $250 \mathrm{~g}$ \\
Potato & 3 (medium) & & \\
Onion & $250 \mathrm{~g}$ & 3 (medium) & 2 (large) \\
Garlic & $1 / 2$ piece (large) & $1 / 2$ (large) & 1 spoon \\
Ginger & $11 / 2$ spoon & $1 / 2$ spoon & $1 / 2$ spoon \\
Pepper & $8-10$ piece & 7 piece & 4 piece \\
Pepper's powder & & $3 / 4$ spoon & $3 / 4$ spoon \\
Tomato & 2 (big) & 2 piece & \\
Sugar & $1 / 4$ spoon & & $1 / 4$ spoon \\
Tasting salt & $1 / 2$ spoon & & \\
Salt & Adequate & $1 / 2$ spoon & $1 / 2$ spoon \\
Turmeric's powder & $1 / 4$ spoon & $1 / 2$ spoon & $3 / 4$ spoon \\
Coriander's powder & $1 / 2$ spoon & & \\
Lemon liquid & 2 spoon & & \\
Egg & 4 piece & & \\
Biscuit's powder & 1 packet $(\mathrm{big})$ & & \\
(without sugar) & & & \\
Soybean Oil & Adequate & 3 table spoon & 3 table spoon \\
Soya sous & $1 / 2$ spoon & & \\
Coriander leaf & Adequate & & \\
Tej pata & 2 leaves & & \\
Masala powder & & & \\
Tamarind sour & & & \\
\hline
\end{tabular}

Taste assessment of stingray recipe: Three stingray recipes served to panelist. All panelists were chosen unabashedly and randomly. Taste of these recipes was assessed by panel testing where 15 persons were included in the panel of which all of them were university teachers. Five parameters were considered each having seven arbitrary ranks (Table 2). Then the percentage of the values got from the panelists were calculated and considered as the final value of the parameters.

Table 2. Taste assessment parameters

\begin{tabular}{lc}
\hline Parameters & Value \\
\hline Excellent & 1 \\
Very good & 2 \\
Good & 3 \\
Medium & 4 \\
Poor & 5 \\
Very poor & 6 \\
Worst & 7 \\
\hline
\end{tabular}

\section{Results and Discussion}

\section{Harvesting of stingray}

Fishermen were asked about the rays harvesting area and depth ranges of fishing. In Bangladesh, stingray is generally found in lower depth water area mainly in coastal area. Stingray is mainly caught by artisanal fishery with gill net, set bag net and long line within 5$40 \mathrm{~m}$ depth ranges. For harvesting, fishermen go about
100-200 km (west direction) and 10-60 km (south direction) from Fishery ghat, Cox's Bazar. Within these distance the harvesting grounds are Sonar char, Ruper char, Char Gongmoti and Dublar char in west direction and Cox's Bazar coast, Teknaf coast, St. Martin coast area and South patches in south direction. Fishermen are also harvested stingray by set bag net or gill net about $60-100 \mathrm{~km}$ at west direction from Fishery ghat, Cox's Bazar. These distances are located in middle ground. Haroon (2011) was found that the prime catching grounds of rays in the south-west region are Kuakata, Sonar char (island), Ruper char, Fatrar char, Char Gongmoti and Dublar char in Patuakhali and Asar Char, Patharghata areas of Barguna and coastal areas of the Sundarbans. In the south-east catching grounds are Sandwip, Kutubdia, Moheshkhali, Cox's Bazar and Teknaf coasts. Sharks are also harvested from the four identified fishing grounds such as, south patches, south of south patches, middle ground and Swatch of no grounds. Bahadur (2011) was found that Sharks including rays are harvested mainly from the coastal areas of Mohipur, Dhal char, Shib char, Sonadia channel and Teknaf coasts of border water areas of Myanmar. It should be noted that the distribution of stingray in harvesting area are gradually decreases. That's why, the area of harvesting are going to be decreases.

During winter season huge amount of stingray is harvested by fishermen. Fishermen harvest stingray every month in a year but December and January considered as suitable for harvesting. Fishermen start journey to the sea for harvesting stingray at the time of both 'joan' (full tide) or 'dala'(neap tide). Bahadur (2011) was evaluated that rays harvesting season spans over September to May. Fishing boats sail for netting sharks and rays during dala period (neap tide) and returns during joan period (full tide). Thus, we identified that harvesting of stingray is increased than before.

Stingray fishing activities are done mostly by long line, shark net, gill net (Lakka jal) and set bag net. Long line has three parts- Main line, Branch line and Hook. The length of main line is between 1000-2000 m and the length of branch line is between 5-15 m and normally six, seven and nine number hook sizes use in long line. Each boat contains three thousand to six thousand hooks. In each feet of main line they put three branch lines and attach one hook in each branch line. Hooks and lines set four times in a day and pull it out of water after $8 \mathrm{~h}$. Fishing was done mainly with long line in low depth water e.g. near shore or off shore water area. The long line operating boats are usually of 40-50 m long and are with 22-35 HP engines. Each boat carries around six crews. Shark nets are of 1500-2200 m long, 10-15 m wide with mesh size is around $400 \mathrm{~mm}$. 'Lakka Jal' is look like large meshed gill nets. These nets are of 3000$4000 \mathrm{~m}$ long, $10-12 \mathrm{~m}$ wide and mesh size is around 220 $\mathrm{mm}$. Fishermen set nets in water and pull it out after $6 \mathrm{~h}$. Sharks net, gill nets (lakka jal) are also operated by wooden mechanized boat. Nets operating wooden mechanized boats are of $12-18 \mathrm{~m}$ long, $4-5 \mathrm{~m}$ wide in middle part with 45-75 HP diesel engines. Each boat carries twelve to twenty eight crews. In stingray fishing, 
fishing gears (nets or hooks) set under water at seven to twenty bams depth (each bam counts as four hands). Long line is very effective to catch large stingrays and avoid small sized stingrays. But all sized stingrays are captured by nets. Haroon (2011) described that sharks are mainly caught by artisanal fishery with drift gill nets used for catching Tenualosa ilisha and Eleutheronema tetradactylum, set bag nets, long lines and trammel nets, shark nets and lakka jal. He found that sharks net are used only in Chittagong areas. However, it was evaluated that using of sharks net are increased and spread in Cox's Bazar area also and rays are also caught as target fishery from the coastal area of Bay of Bengal.

\section{Available species in the market}

In the present study, only six species of stingray are found during the study period in fishery ghat, Cox's Bazar. Among these species, Himantura gerrardi and Himantura bleekeri is abundant stingray in market. These two species are highly acceptable by the local people for consumption. Dasyatis bennetti, Himantura undulata and Himantura uarnak are also found in market. Neotrygon kuhlii is found sometime in market in rare case. It is less accepted by local people. Haroon (2011) discovered that total thirty nine species of rays were so far recorded from Bangladesh waters. Jit et al. (2014) also mentioned that sixteen species of rays belonging to nine families were recorded. It should be noted that the number of species of stingray is decreasing in harvesting areas.

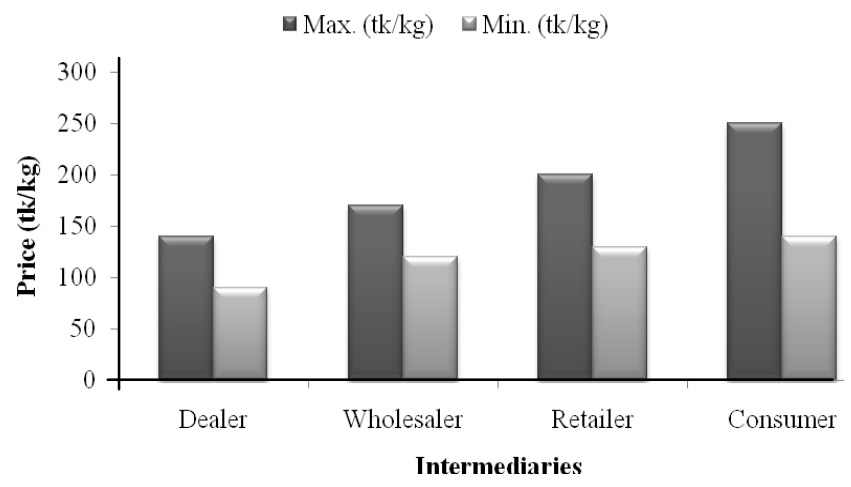

Fig. 1. Local market value chain

\section{Market chain value}

The rate of the fresh meat of stingray for consumer in local and supply market varied at range 140-250 Tk/kg (Fig. 1) and 180-250 Tk/kg (Fig. 2), respectively. Roy (2011) stated that rays' fresh meat is sold at $50-80 \mathrm{Tk} / \mathrm{kg}$ in local market and sun-dried rays' skins (dorsal part) and tails are exported abroad. Bahadur (2011) mentioned that Fresh/iced meat of stingray was at $65 \mathrm{Tk} / \mathrm{kg}$ and cut pieces, salted, sun-dried meat of stingray was sold at $180-250 \mathrm{Tk} / \mathrm{kg}$. It should be noted that the rate of stingray is increasing due to consumer acceptance.

\section{Proximate composition}

The proximate composition of Himantura bleekeri was presented in the Fig. 3. The average moisture content was determined as $78.08 \%$. The protein content was found as $14.80 \%$. The lipid content was determined as $4.31 \%$. The carbohydrate content was found as $0.95 \%$. The ash content was found as $1.87 \%$. The energy content was determined as $103.78 \mathrm{Kcal}$ from Himantura bleekeri. Mazumder et al. (2008) mentioned that the proximate composition of some small indigenous fish species i.e. protein was estimated $18.46 \%, 15.23 \%$, $14.08 \%, 18.26 \%, 15.84 \%, 16.99 \%$ in Amblypharyngodon mola, Gudusia chapra, Puntius chola, Chanda nama, Pseudeutropius atherinoides and Ailia coila, respectively. Fat content was recorded as $4.10 \%, 5.41 \%$, $3.05 \%, 1.53 \%, 2.24 \%$ and $3.53 \%$, respectively. It is found that stingray has high nutritional significant as like as small indigenous fish.

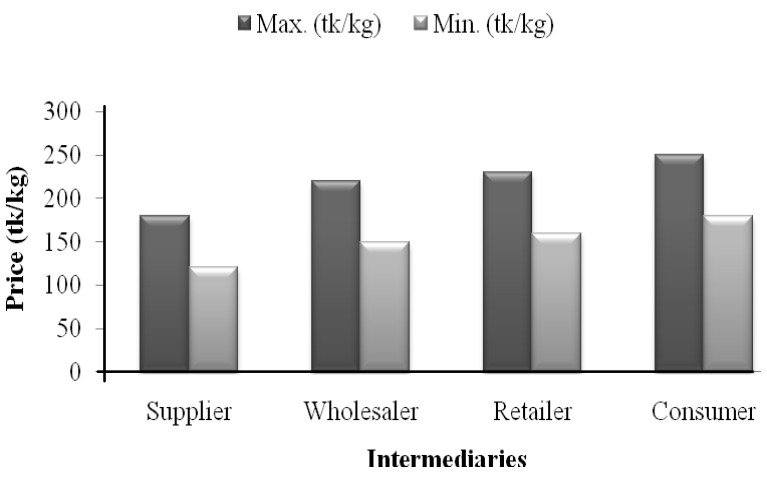

Fig. 2. Supply market value chain.

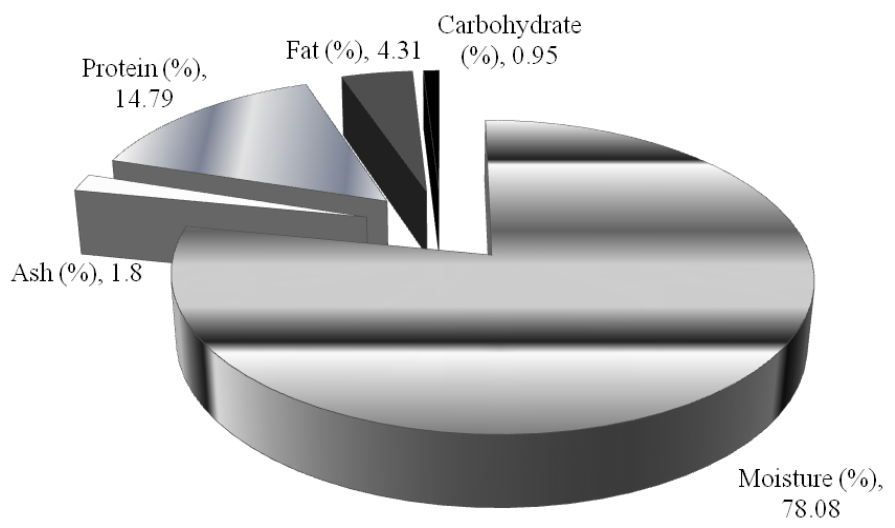

Fig. 3. Proximate composition of Himantura bleekeri 


\section{Utilization of stingray}

Stingrays are used as food for human consumption and preparing fish meal as livestock feed. Compagno (1984) mentioned that small sized of rays are used for producing fish meal and fertilizer for fish culture pond. The utilization of stingray for food is mostly by the poorer sections of the people in Bangladesh. The meat of many stingray species is white or slightly pinkish and juicy. In accordance with Roy et al. (2014) the meats of H. undulata are consumed by non-Muslim people in the local market of Bangladesh. In the present study, it was found that stingrays are also consumed by many Muslim people in the study area and its rate of consumption is gradually increasing. Three products of stingray were prepared and preferred as very good products by test through consumers in the present study. These are namely fish ball of stingray, stingray recipe with sour of tomato and stingray recipe with sour of tamarind. However, fish ball of stingray was preferred very much than others product of stingray. It is also a value added product. It was categorized as excellent product and highly consumer acceptance. Peoples like to consume new recipe or new things. Fish ball of stingray can be preferred as a new recipe or new product for daily consumption which may fulfill the lack of nutrients. Rays are mostly utilized as fresh meat, dried and smoked formed (Roy, 2011). In the present study it was found that Muslim and Hindus peoples of Bangladesh utilized rays as fresh meat with different masala elements by cooking. Roy et al. (2014) mentioned that dorsal part skin of rays are exported as dry condition to make bags, money bags and shoes etc. which was similar with the present study. A special feature of stingray is the surface of the skin is a kind of rough leather with dermal denticles embedded in the skin, used for rasping and polishing. The skin can also be converted into fancy leather by removing the dermal denticles. A few numbers of stone like things are seen in dorsal part of stingray which may determine the rate of skin. The rate of skin is also determined by its height, width and size of stingray. After collecting skin, it is preserved by salting. This leather can be used for shoes and other value-added products such as wallets, dress belts, watch belts, handbags, shoes and wood polish paper etc. The operation of skinning and salting must not take more than $24 \mathrm{~h}$. For drying, the meat is kept in one piece. Salt is used for primary preservation. Then the meat is cut up to into medium pieces and washed in water. The pieces of meat are then placed into the brine tank for three days before rinsing in seawater and being put out to dry on the roof mostly. Sun drying lasts for around six days or more depending on heat of the sun. After drying, the dried meats are packed in polythene bag and supply in the local market or export market. Haroon (2011) described that the utilization of elasmobranches fishes for food is mostly by the poorer people in India, Bangladesh, Myanmar, Sri Lanka and the Maldives as the flesh is considered not quite wholesome.
Due to climate change, intrusion of saline water in the fresh water bodies is increasing day by day. The fresh water fish species are decreasing. That's why, peoples are going to depends on the marine water fish species rather than fresh water species.

\section{Conclusion}

The study was conducted to know the harvesting system, marketing channel, nutritional value and utilization process of stingray in Bangladesh. Stingray is caught as artisanal fishery by nets and caught as target species by long line gears. The marketing channels were controlled by intermediaries such as fishermen, wholesaler, dealer, retailer, supplier and consumers. Stingray was distributed others cities by supplier. The market value of stingray was varied with the types of marketing channels. The value of stingray is also varied with season to season and species to species. Stingray was high priced in winter season. White Whiptail stingray was considered as high priced than others. Medium sized stingray was good priced in market. Only six species of stingray were identified at fish landing center in Cox's Bazar but only Himantura gerrardi and Himantura bleekeri were available in market and also highly acceptable for consumers. High lipid and protein content in Himantura bleekeri. Mainly Tribal, Hindus, Baddish and few Muslims are utilized fresh meat of stingray in several ways. Stingray dried meat was utilized by only tribal people. The fresh meat of stingray was utilized by cooking with tomato or tamarind sour. Stingray fresh meat was used to make fish ball which preferred as an excellent category food product of stingray through panel taste. The others two products such as, stingray recipe with sour of tomato and with sour of tamarind were also preferred as very good and good categories, respectively. All of the ingredients were used to make these recipe are available in market. Preservation of skin was done by salting and drying and supplied these to processing plants for export in abroad namely China, Thailand, Singapore, Myanmar etc.

\section{References}

Bahadur, H. I. 2011. Trades of shark products in Bangladesh. Shark Fisheries in the Bay of Bengal, Bangladesh: Status and Potentialities, pp. 43-50.

Bonfil, R. and Mohamed, A. 2003. FAO Species Identification Guide for fishery purposes. Field Identification Guide to the Sharks and Rays of Red Sea and Gulf of Aden, Jeddah, Rome.

Carr, M. A., Miller, M. F., Daniel, D. R., Yarbrough, C. E., Petrosky, J. D. and Thompson, L. D. 1997. Evaluation of the physical, chemical and sensory properties of jerky processed from emu, beef, and turkey. Journal of Food Quality, 20(5): 419-425. https://doi.org/10.1111/j.1745-4557.1997.tb00484.x

Compagno, L. J. V. 1984. FAO species catalogue, Shark of the world; Part 2 Carcharhiniformis. Food and Agriculture Organization of the United Nations, Rome, Italy, 4: 655.

DoF. 2014. Fisheries statistical year book of Bangladesh. Department of Fisheries, Matshya Bhaban, Dhaka, Bangladesh.

DoF. 2015. Fisheries statistical year book of Bangladesh. Department of Fisheries, Matshya Bhaban, Dhaka, Bangladesh. 
Haroon, A. Y. 2011. Shark fishery in the Bay of Bengal, Bangladesh. Shark Fisheries in the Bay of Bengal, Bangladesh: Status and Potentialities, pp. 11-32.

Hussain, M. G. and Rahman, M. J. 2010. Marine fisheries resources of Bangladesh: Stock status and management issues. Sustainable Management of Fisheries Resources of the Bay of Bengal. Support to BOBLME Project, Bangladesh Fisheries Research Institute, Bangladesh, pp. 37-51.

Jit, B., Alam, M. F., Rhaman, M. G. and Singha, N. K. 2014. Landing trends, species composition and percentage composition of sharks and rays in Chittagong and Cox's Bazar, Bangladesh. Global Journal of Science Frontier Research, 14(4).

Mardiah, A., Huda, N. and Ahmad, R. 2010. A study on the physicochemical properties, microstructure and sensory characteristics of fish flakes. Journal of Fisheries and Aquatic Science, 5: 469-482. https://doi.org/10.3923/jfas.2010.469.482

Mazumder, M. S. A., Rahman, M. M., Ahmed, A. T. A., Begum, M. and Hossain, M. A. 2008. Proximate composition of some small indigenous fish species (SIS) in Bangladesh. International Journal of sustainable crop production, 3(4): 18-23.

Quddus, M. M. A., Sarkar, M. N. and Banerjee, A.K. 1988. Studies of the Chondrichthyes Fauna (sharks, skates and rays) of the Bay of Bengal. The Journal of Noamii, 5(2): 19-23.
Roy, B. J. 2011. Catch monitoring and assessment of shark and allied fisheries in the Bay of Bengal. Shark Fisheries in the Bay of Bengal, Bangladesh: Status and Potentialities, pp. 33-42.

Roy, B. J., Ali, S.M. H., Singha, N. K., Rahman, M. G. and Alam, M. F. 2014. Shark and rays fisheries of the Bay of Bengal at the landing centers of Chittagong and Cox's Bazar, Bangladesh. Global Journal of Science Frontier Research D, 14(5): 78-89.

Roy, B J., Singha, N. K., Ali, S.M. H., Rahman, M. G. and Alam, M. F. 2014. Status of vulnerable leopard whip ray (Himantura undulata) at two landing centres of Chittagong and Cox's bazar, Bangladesh. Bangladesh Journal of Zoology, 42(1): 11-17. https://doi.org/10.3329/bjz.v42i1.23332

Swastawati, F., Susanto, E., Cahyono, B. and Trilaksono, W. A. 2012. Sensory evaluation and chemical characteristics of smoked stingray (Dasyatis blekeery) processed by using two different liquid smoke. International Journal of Bioscience, Biochemistry and Bioinformatics, 2(3): 212. https://doi.org/10.7763/IJBBB.2012.V2.103

Ünlüsayin, M., Gümüş, B. and Erdilal, R. 2011. Proximate analysis of some ray species caught by trawling in Mediterranean Gulf of Antalya (Turkey). In International Conference Aquaculture and Fishery, 5, Belgrade (Serbia), 1-3 Jun 2011. 